\title{
AN INTERNATIONAL SYMPOSIUM ON INSTRUCTION IN THE MECHANICS OF FLUIDS
}

\section{SYMPOSIUM INTERNATIONAL SUR L'ENSEIGNEMENT DE LA MÉCANIQUE DES FLUIDES}

\section{JAPANESE ENGINEERING EDUCATION IN THE MECHANICS OF FLUIDS}

BY TAIZO HAYASHI *

One of the features of today's university education in Japan is its very large scale. Moreover, it has become quite different in concept as well as extent from that before the War. After the War, the policy of democratization of higher education was stressed, and many junior colleges were upgraded to universities. According to recent statistics, the number of university students is at present about a quarter of the population of the same age, this ratio having been that of junior high school education before the War. The stress of such development may have brought about a certain depression of the average standards of Japanese universities. However, in view of the remarkable economic progress which Japan has realized, this educational development seems justified. The lowering of the average standards of universities can be seen as an unfortunate by-product of an otherwise successful system.

As an example of the enormous expansion in the number of colleges of engineering, it may be noted that, at present, there are 58 colleges having departments of civil engineering (27 national universities, 2 local-government universities, and 29

\footnotetext{
* Hydraulic Laboratory Chuo University, Tokyo, Japan.
}

private universities) in spite of the fact that on the Japanese Islands before the War only 5 colleges of engineering had civil engineering departments (4 national universities and 1 private university).

Japanese university education consists of four years of undergraduate study, two more years of study for the master's degree, and three additional years of doctoral study. In this connection and with respect to the department under consideration, universities can be divided into three categories: those having all three levels of education; those having undergraduate and master's levels; and those offering only undergraduate courses. However, all universities in the lower categories have been endeavouring to be upgraded to the first category. Courses in undergraduate colleges of engineering lead to Kôgakushi (Bachelor of Engineering), master's studies in graduate schools of engineering lead to Kôgaku-shûshi (Master of Engineering), and doctoral studies lead to Kôgakuhakushi (Doctor of Engineering). One could as well translate Kôgakushi into English as Bachelor of Science, Kôgaku-shûshi as Master of Science, and Kôgaku-hakushi as Doctor of Philosophy.

Courses in the mechanics of fluids are usually offered independently in the departments of civil 
engineering, mechanical engineering, naval architecture, aeronautics, etc. The characteristics of the courses vary, of course, from one university to another. However, some common traits seem to exist in each of the above-mentioned departments. In the department of civil engineering a typical sequence of fluid mechanies in the undergraduate curriculum may cover hydrostatics, the kinematics and dynamies of fluid flow, basic hydrodynamies, dynamical similitude, flow measurement, flow through pipes, flow in open channels, unsteady flow in pipes and open channels, immersed bodies, waves on still water, sediment transport, ground-water flow, etc. Besides a course in fluid mechanics, a course in hydrodynamics is offered at most universities. A typical sequence of this course covers potential flow, boundary layer, flow of viscous fluid, etc. In graduate-school education, lectures are given on flow in open channels, waves on still water, turbulence and diffusion, and so on. In the department of mechanical engineering a large part of flow in open channels and waves on still water is abbreviated. Instead, considerable emphasis is laid on hydraulic machinery, immersed bodies, ete. In the department of aeronautics, emphasis is laid on gas dynamies.

The courses in fluid mechanics in undergraduate schools comprise from 60 to 120 lecture hours, depending on the university. The course in hydrodynamics comprises from several to 30 lecture hours. Besides these courses in fluid mechanies and hydrodynamics, many courses in hydraulic engineering are offered in undergraduate schools. For example, in the department of civil engineering, courses in hydrology, river engineering, coastal engineering, sanitary engineering, and water power engineering are offered in almost all universities.

The degree Master of Engineering is awarded upon the satisfactory completion of an approved program of study for at least two years and the completion of an acceptable thesis. The degree Doctor of Engineering is awarded upon the salisfactory completion of an approved program of study for at least three more years and the completion of a thesis. During such study, few formal lectures are offered, postgraduate students being engaged only in research. Unlike in the United States, there is no flexibility between undergraduate courses and graduate courses.

There were graduate schools before the War also, but their concept was quite different. Postgraduate students were engaged only in research. Influenced by this former system, a large number of those who studied in universities before the War now incorrectly assume that advanced studies have the purpose of teaching only "difficult things" and cultivating only researchers. Consequently, a majority of the people in industry demand students from the undergraduate colleges rather than postgraduate students. Another reason for this situation is that the engineering education in undergraduate colleges seems to be complete in itself. In almost all such colleges, each student is required to complete a thesis which usually consists of a project of an applied or design nature or of experimental or theoretical research. In the case of experimental research, a group of two or three students may work together and may submit one common thesis. Students specializing in fluid mechanics and hydraulic engineering spend most of their time, except class hours, during their final year in the hydraulic laboratory. They participate actively in experiments, and their contribution to research is an important factor which should not be disregarded in the fluid mechanics research in Japan.

Now that nearly twenty years have passed since the New Education System in Japan started after the War, the system has come to be a subject of discussion. The lack of flexibility now existing between undergraduate courses and graduate courses, the longer periods of study in the minimum requirements for either the master's or the doctor's degree in comparison with the system in the United States, and some other points must now earnestly be examined.

According to the questionnaire on civil engineering university education recently distributed by the Japan Society of Civil Engineers to about 800 civil engineers, approximately $70 \%$ of the respondents considered that four-year undergraduate education is too short and should be extended to five years. This answer can be interpreted to mean that more emphasis was placed on undergraduate education than graduate, which most of the respondents seem to have considered as producing researchers only. However, in view of the fact that master's courses are intended to produce not only researchers but also people who have wide professionnal knowledge as well as firm knowledge of engineering science, this answer may also be considered to be a request for a suitable combination of undergraduate and graduate education.

Probably the single book which had the greatest influence on hydraulics and hydraulic engineering in Japan before the War was Mononobe's "Suirigaku" (Hydraulics) of 1933 . It was an extensive book beyond comparison at that time, almost like an encyclopaedia, which was used by hydraulic engineers at least up to 1955. In 1948 the second edition of "Suiri-kôshikishu" (Hydraulic Manual), edited by the Japan Sociely of Civil Engineers, was intented to take the place of Mononobe's "Hydraulics," already in need of updating. The contents of the manual consist of four parts: river hydraulies, water-power hydraulies, hydraulies in sanitary engineering, and maritime hydraulies. One may readily see, even from this classification alone, the traditional emphasis on applied hydraulics in Japan at that time.

The book on hydraulics in which stress was first laid on the mechanies of fluids was probably Oki's "Suirikigaku" (Hydraulics) of 1942. The emphasis of the mechanics of fluids either in hydraulics or hydrodynamics became more evident in Homma's "Suirigaku" (Hydraulics), 1952, or Tani's "Nagaregaku" (Fluid Mechanies), 1951, respectively. Ishihara-Hom-ma's "Oyossuirigaku" (Engineering Fluid Mechanics)-three volumes, 1957 , 1958, 1959-had great influence on hydraulics also. Within the last ten years, more than ten books have been published as textbooks or reference books on fluid mechanies. 
Generally speaking, in undergraduate education more emphasis is placed on hydraulics than on fluid mechanics, and in postgraduate education vice versa. One reason why this is true is the demand from industry, where emphasis is traditionally put on practice. Another reason is the effort to raise interest through practical phenomena in students who are likely to believe that fluid mechanics is a subject having a unique structure that is quite hard to understand.

In most undergraduate schools, students participate in experiments on hydraulics. Generally speaking, however, Japanese professors are more enthusiastic about their own researches than about teaching, and the facilities for demonstration are relatively poor. Few films have been edited in Japan for instruction in fluid mechanics, although the importance of the motion picture in fluid mechanics education has been fully recognized.

Having been stimulated by the "Groals Study" which was recently undertaken by the American Society for Engineering Education, a proposal has been publicized for the rearrangement of the engineering college curriculum into one in which subdivision among the existing departments is eliminated. The courses in fluid mechanics, which are at present offered separately by various departments, will be combined and more basic aspects of the subject will be taught. Following the courses in fluid mechanics, a course in heat and mass transfer will be offered. In view of the necessity of some sort of educational reform of Japanese university education in the future, this kind of study must not be underrated.

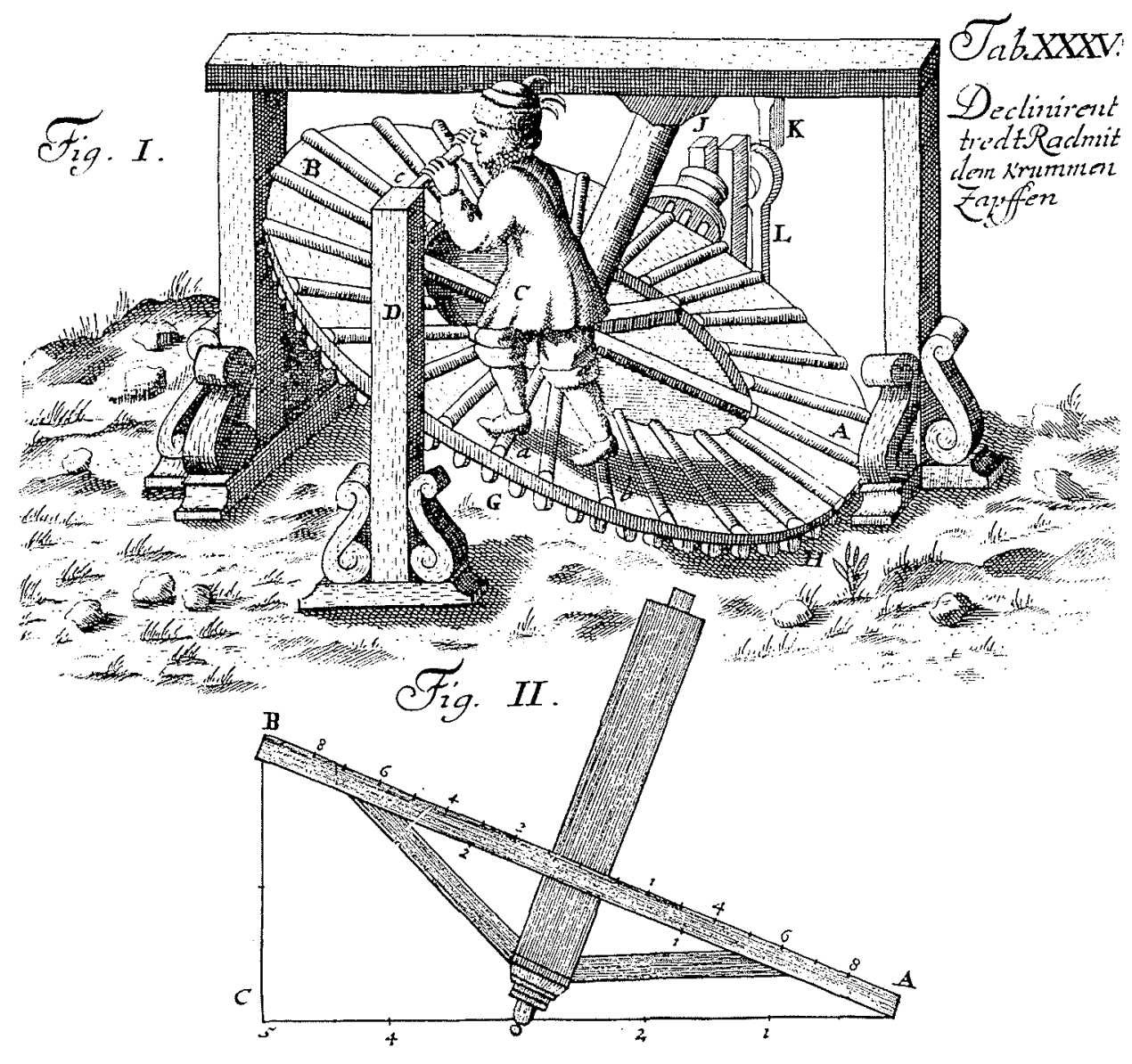

